\title{
New Official Ideas on Women and Development
}

\section{Ingrid Palmer}

Much of the latest thinking in international circles focuses on the integration of women in development programmes. While even the most sympathetic approaches remain at the stage of considering remedial or corrective action, to ignore them would be unimaginative, for they can act as a catalyst for more fundamental change. More importantly, we must understand the thinking behind these official recommendations in so far as they are likely to affect women.

Many of these new ideas and recommendations are based on the analyses made in the ILO's selected country mission reports and urban studies of the problems of employment and poverty. These are: Rural Employment Problems in the United Arab Republic (1969); Towards Full Employment: A Programme for Colombia (1971); Employment. Incomes and Equality: A Strategy for Increasing Productive Employment in Kenya (1972); Employment and Unemployment in Ethiopia (1973); Employment in Africa. Some Critical lssues (1973); Joshi, et. al. Abidjan: Urban Development and Employment in the Ivory Coast (1976); Lubell, Calcutta: Its Urban Development and Employment Prospects (1976); Schaefer, Saõ Paulo: Urban Development and Employment (1976); and Sethuraman, Jakarta: Urban Development and Employment (1976). This article reviews these reports ${ }^{1}$ and their recommendations particularly as they affect women, and then goes on to review briefly the Basic Needs Strategy based on them and the implications for women of the New International Economic Order.

The publication of the reports of the ILO comprehensive country employment missions led to a considerable reassessment of development thinking. The mission to Colombia was shocked by current estimates and projections of unemployment and took refuge in wildly ambitious future growth rates. To close the floodgates of rural-urban migration it recommended a minifundia, family-based 'green revolution', since this would promote a more intensive use of labour and land. reduce massive migration, as well as recommending the informal urban sector, and suggesting ways of

\footnotetext{
1 Referred to hereafter as ILO/UAR. ILO/Colombia. ILO/ Ceylon. ILO/Kenya. ILO/Ethiopia, ILO/Africa, ILO/ Abidjan, ILO/Calcutta, ILO/Saó Paulo, ILO/Jakarta.
}

raising employment and labour'productivity within it. The subject of women was directly raised in the Kenya report due to the importance of womenheaded households, particularly in rural areas. It was elaborated in the analysis of the informal sector through a discussion of the 'working poor'; that is, it was suggested that the problem of underdevelopment stemmed less from open unemployment than from the inadequacy of income from low-productivity employment.

\section{The employment data base for policy recommen- dations}

Because of unequal data availability the four studies of urban employment and development were variable in quality. In this respect they clearly posed the problem of the data base upon which policy recommendations are made.

Because of the scarcity of hard information most of the ILO reports were largely general overviews. Little of the data on unemployment and underemployment is broken down by sex so it is difficult to evaluate the employment recommendations for women. The conclusions of the reports are also suspect because the data on women's employment and unemployment, when it is available, is definitionally questionable. The data on female agricultural employment is particularly suspicious.

The labour force is defined as those employed plus those seeking employment (including those seeking work for the first time); the labour force participation rate is estimated by taking this total as a percentage of the population of working age. The data on employment are supposed to cover employers, the self-employed, salaried employees and wage earners, unpaid family workers, members of cooperatives, and members of the armed firces. But the numbers of hours that have to be worked per day to qualify as employed differs from country to country. Moreover these hours have to be occupied in the main line of work, which excludes people working in several types of production or services. Many women, especially those in the informal urban sector or working as unpaid family workers, are likely to be left out of this accounting.

The other part of the labour force estimatesthose seeking employment or unemployed-is also suspect for women. It is doubtful whether many 
women spend time actively seeking work since they are occupied with their household tasks. Again many people, but particularly women, give up actively seeking work when it is known that there are few jobs available, or they may consider that their half-hearted informal searching for a job does not amount to actively seeking work. Finally there may be cultural inhibitions restraining women from admitting that they are seeking work. Ironically persons occupied in some side-line for a few hours a day, again notably women, may not be included in statistics on either the employed or the unemployed. When countries return statistics showing that only 25 per cent of women are in the labour force, while double that rate is recorded for men, something is clearly wrong in the data collection. Unfortunately the ILO does not publish labour force participation rates separately for urban areas where the data might be more accurate.

The published participation rates (activity rates) for men and women illustrate official conceptions of the two sexes' participation rates and indicate the possible extent of underestimation of actual female unemployment rates. Since the biases in recording overall women's participation rates and unemployment rates are not comparable between countries, nor are they representative of urban women's rates, recourse has to be made to sample surveys.

The Saõ Paulo report gives a male unemployment rate of $\mathbf{9 . 6}$ per cent and a female unemployment rate of 3.6 per cent for 1969 (ILO/Saõ Paulo: 36). In contrast the Kenya report shows that the proportion of females seeking work in Nairobi is higher than that for males in all age groups except that of 20-24 years (ILO/Kenya: 58). Over all age groups the percentages were 30 and 16 per cent respectively, while between 25 and 29 years of age, 46 per cent of women were seeking work compared with only 13 per cent of men.

The Sri Lanka report provides detailed unemployment data in the form of the percentage of the labour force in the urban, rural and estate sectors, seeking work by age, sex, and level of education. Rates for women were much higher than for men in all categories (except in the case of estate workers without ' $O$ ' level education) (ILO/Ceylon: 27). Over all ages, women's unemployment rate was double that of men!

A rate of unemployment of 3.9 per cent for women and 7.1 per cent for men was recorded for Jakarta in 1971. However (ILO/Jakarta: 64), with a recorded female labour force participation rate as low as 20.4 per cent, compared with 65.7 per cent for males, the former unemployment rate is hardly credible. If it were assumed, not unreasonably, that 40 per cent of females would take employment if it were available on conditions roughly commensurate with their skills, then the female unemployment rate would rise to 52 per cent.

A comparison of the unemployment data of Saõ Paulo and Jakarta, on the one hand, and of Kenya and Sri Lanka, on the other, leads to the speculative conclusion that the lower the recorded levels of unemployment, the more likely it is that female unemployment will be lower than male unemployment. That is to say, when there are 'inhibitions' in the statistical collection of unemployment figures, they are distinctly stronger concerning female unemployment.

Many of the later reports discuss underemployment, which is defined in two widely different ways:

-Visible underemployment occurs when a person involuntarily works part-time or for shorter than usual periods of work. This includes seasonal unemployment;

-Invisible underemployment occurs when a person's working time is not abnormally reduced but the employment is inadequate in terms of not utilizing his/her skills, where productivity or earnings are abnormally low. Invisible underemployment can therefore include a situation of overwork which produces an inadequate income.

The most detailed information on (visible) underemployment comes from Latin America and this is estimated in terms of its unemployment equivalent and added to data on open unemployment (ILO/LA: 38).

The data are presented in Table 1 as an illustration of how high total unemployment 'equivalents' can be, and therefore an indication of the employment situation facing women, on the assumption that both their unemployment and underemployment rates are worse than men's.

The only hint of a sex breakdown is given in an unfortunate passage which states that (visible) underemployment in rural areas of Latin American countries has been estimated as more than twice the national open unemployment rate, and that, although open unemployment is more serious for the individual involved, 'most of the 
unemployed are young people and married women ... while unemployment rates for heads of household are usually only a fraction of the corresponding total figure' (ILO/LA: 19-20). The throw-away comment on unemployed young men and women of all ages (for that is what it amounts to) can only be based on a fatuous assumption that women are being kept by someone, somewhere. It would be interesting to know, therefore, why a married woman would bother to record herself as being in the labour force yet unemployed. The implied assumption that a head of household can only be a man is particularly outrageous for Latin America with its many forms of liaisons between men and women. The report points out that it is important to consider who are affected by employment problems' and that 'an unemployed head of household means a very serious drama for the whole family'. It fails to ask what proportion of married women recorded as openly unemployed are effectively heads of household.

The report's projections of employment and unemployment to the year 2000 suggest that the modern sector will absorb even smaller percentages of the labour force than in 1970, inspite of an assumed annual growth rate as high as 6.6 per cent. The result will be a slightly higher increase in underemployment but almost a doubling of the open unemployment rate. In urban areas, the rate of open unemployment plus the unemployment equivalent of underemployment is expected to rise from 26 per cent in 1970 to 60 per cent in 2000. It also estimates a widening of the labour productivity differential between the traditional and modern sectors. Since women tend to congregate in the former, and the scarce jobs in the latter tend to go to men, this suggests that women's underemployment will increase faster than men's.

\section{The concept of adequate employment}

One of the strengths of the ILO reports, particularly the one on Kenya, was that they pointed out that the poor often worked very long hours for very little return. The development problem is thus not unemployment, but employment; that is, of low productivity and poorly remunerated work (i.e. invisible underemployment). The Kenya report used the notion of 'inadequate employment' to develop its concept of the working poor, largely found in the generally urban informal sector in which activities were characterised by indigenous resources (including skills obtained outside the formal education system); family ownership and small scale of operation; labour-intensive and adapted technology; and unregulated and competitive markets.

While the reports also refer to the rural informal sector, mostly traditional family-based agriculture, they fail to point out that its low productivity and long working hours apply very largely to women only: seasonal unemployment or short working hours being a characteristic of the male agricultural labour force in most areas. Furthermore unpaid female family labour is by definition

Table 1

Total labour force underutilization around 1970 in selected Latin American countries (percentages)

\begin{tabular}{l|l|l|c|c|c}
\hline & $\begin{array}{l}\text { Unemployment } \\
\text { equivalent of open } \\
\text { unemployment } \\
\text { PLUS } \\
\text { underemployment } \\
\text { in agriculture } \\
(1)\end{array}$ & $\begin{array}{l}\text { Open } \\
\text { non-agricultural } \\
\text { unemployment }\end{array}$ & $\begin{array}{l}\text { Non-agricultural } \\
\text { underemployment }\end{array}$ & $\begin{array}{l}\text { Unemployment } \\
\text { equivalent of (3) }\end{array}$ & $\begin{array}{l}\text { Total labour } \\
\text { underutilization }\end{array}$ \\
\hline Argentina & $(2)$ & $(3)$ & $(4)$ & $(5)$ \\
Brazil & 10 & 1.9 & 27.8 & 12.0 & 13.6 \\
Colombia & 25 & 6.9 & 43.5 & 21.8 & 32.2 \\
Chile & 20 & 7.4 & 39.2 & 20.8 & 29.6 \\
Mexico & 35 & 5.0 & 37.9 & 17.3 & 22.8 \\
Venezuela & 19 & 5.8 & 27.9 & 11.8 & 25.4 \\
\hline
\end{tabular}

Source: ILO/LA

N.B. Rural underemployment here is estimated from census data for supply and demand of labour and data on labour inputs for each commodity. It therefore includes seasonal unemployment. Urban underemployment is calculated from income distribution data such that a person with lower than a certain income is deemed underemployed. 
different from the inadequately remunerated working poor-yet none of the ILO reports noted this category of women workers. The implication is that if labour productivity is to be raised to produce a marketable surplus through a green revolution, the family based nature of small farms may inhibit women's access to an adequate income.

In the case of Kenya, the working poor were more specifically defined as those persons earning less than 200 shillings a month. The report does not indicate whether this is the poverty line for the individual or for a growing family. We are simply told that this level is 'reasonable also in the sense of representing a standard of living which would generally be considered ... to correspond to the minimum standard needed to avoid real poverty and deprivation' (ILO/Kenya: 60). The figure was also chosen because it was the 1972 equivalent (in terms of purchasing power) of the official minimum wage adopted six years previously for Nairobi and Mombassa. Yet minimum wages in formal factory employment in developing countries are scarcely adequate to reproduce a family, and there is widespread suspicion that minimum wages find their level at just maintaining the individual worker. Even when the Kenya report addresses the problem of relating individual earnings to household earnings (possibly with several members in gainful employment), it is still not clear how many persons' poverty and deprivation 200 shillings a month is supposed to avoid. More seriously, this simplistic analysis, by implying that turning inadequate employment into adequate employment for men is a substitute for finding jobs for women, detracts from the urgency of creating more jobs so that the largely unrecorded open unemployment of women is reduced.

As can be seen, the report showed that 32 per cent of the female labour force in Nairobi earned less than 200 shillings a month, as against 14 per cent of males. Furthermore over half the households headed by women appear to have no visible income (11 per cent) or less than the critical level of 200 shillings a month (41 per cent). The corresponding figures for male heads of household were 14 and 15 per cent respectively. Part of this difference can be put down to the preponderance of women in the informal sector. In 1969 only 25,800 women were employed in the formal sector in Nairobi against 137,800 men; in all Kenyan towns 36,400 women were employed in this sector against 267,000 men.

The report's optimism that the informal sector could be a source of growth and vitality and of a new strategy of development ignores two things: firstly, the common prediction that in future the informal sector will include a large proportion of the urban labour force with consequent greater crowding and more intensive underemployment. Secondly that the nature of women's work in the informal sector, such as domestic service, prostitution, and probably much of the backroom garment industry, does not lend itself to upgrading measures. Curiously enough this was not a result of the report writers being unaware of the nature of urban women's work, or their assumption that it was unimportant because women can always depend on some male for support. On the contrary, they put woman-headed households on the official map and were so concerned about the position of women that they regretted having no member of the mission devoted entirely to looking at women's issues. Their difficulty, perhaps, was in sustaining concentration on women's issues through to the recommendations stage.

The main point here is that while in male headed households the spouse may also be earning, female headed households have to depend on the earnings of children to supplement the head's income. This suggests that not only must priority be given to finding work of any kind for female household heads, but that if the upgrading of the informal sector is to be taken seriously, then a principal goal must be upgrading the work of employed female household heads.

\section{Table 2}

Proportion of unemployed persons and of the working poor in the adult population of Nairobi, by sex and household status, 1970 (\%)

\begin{tabular}{l|c|c||c|c}
\hline & \multicolumn{2}{|c}{ Females } & \multicolumn{2}{c}{ Males } \\
\cline { 2 - 3 } & heads of household & all household members & heads of household & all household members \\
\hline Unemployed & 10.8 & 22.8 & 4.9 & 10.0 \\
Working Poor & 40.7 & 31.8 & 13.8 & 13.6 \\
\hline
\end{tabular}

Source: ILO/Kenya: 64 


\section{Migration and the imbalance between rural and} urban sectors

The imbalance between employment opportunities in rural and urban areas has been one of the major concerns of recent development strategies. A number of recommendations for increasing agricultural production have attempted to counter the motivations of migrants. But has this latest thinking included sex specific differences? If it can be shown that men and women view their life options differently, then offering incentives to match the rural male's ideas alone may be inadequate.

It is well-known that most migrants in Latin America both historically and currently have been women. What is less well-known is that this is now apparent in other regions. Most migrants to Abidjan are now women, whether single women, or wives coming to join their husbands. In Egypt, according to the 1960 census, there were 104 males to every 100 females in the age group 15 to 65 years in urban areas, but more females in the 10 to 24 years age group (ILO/UAR: 29). This has been put down to the migration of girls to the cities seeking jobs as domestic servants. In Jakarta while in 1961 there were 1,038 males to every 1,000 females, by 1971 there were 1,021 males, but in the 15 to 23 year age group there were actually fewer males than females (ILO/Jakarta: 54-5). Another interesting point is that between 1961 and 1971, the proportion of unmarried men and women over 10 years of age increased significantly from 41 to 48 per cent for males and from 26 to 35 per cent for females. There would also appear to be an increase in never married or divorced women living on their own. In urban Ethiopia in 1970 there were believed to be 189,000 divorced women compared to 39,000 divorced men, which suggests that divorced rural women choose to migrate to urban areas much more often than divorced rural men (ILO/Ethiopia: 124).

In spite of the pronounced female migration most of the commentary on motives for migration refer to men. The attraction of the towns for the migrants is that there they can get on:

"The basic reason is that these youngsters are desperately keen to get on in the world, and are convinced that this is only possible in the towns. . . For such youngsters, rural society is the epitome of the archaic and the antithesis of progress" (ILO/Africa: 181).

When, as is so common, the rural-urban wage differential is included in the analysis, the economic means for getting on is also supplied. Even after weighing the probabilities and risks of facing a period of unemployment or underemployment on arrival in a town, the belief in a future better economic position is said to be incentive enough to migrate. This reasoning is not entirely satisfactory in the case of women. For them it is not simply a matter of whether the returns to their labour are higher or lower. Urban residence for women signifies wage labour or cash in hand, perhaps for the first time. A woman could be described as behaving in an economically rational way by moving to even lower productivity work, if that work brought her more control over the returns to her labour. Thus it may not be in response to productivity or wage differentials that a woman is motivated to leave the rural life, but rather in order to find a total new mode of economic livelihood. Moreover, since fewer female migrants than male migrants are literate, women entertain fewer illusions about education and its ability (eventually) to bring them a better paid job in the urban formal sector. They tend instead to move quickly into the informal sector to gain a livelihood, adopting a survival strategy as different from that of men as their motives for migrating in the first place.

The ILO Abidjan report recognises both these aspects of women's migration:

"The wives who come to the city in many cases benefit considerably from the move. They escape their rural responsibilities for cultivation, and do not necessarily lose personal autonomy despite their reduced economic roles. However, the migration of wives is not the only source of female migration to the towns that is not directed towards obtaining employment. Many Ivory Coast women decide of their own free will to migrate more as an assertion of independence from men folk at home than at the latter's bidding. ... This migration is to a minor extent directed at the urban job market but predominantly, at the urban market for husbands or other kinds of partners" (ILO/ Abidjan: 34).

Taken at its face value there is something of a contradiction in this. Why move from dependence on rural men to dependence on urban men? There is an implicit assumption that social relations between sexual partners are less oppressive to women in urban areas than in rural areas. But since it is well known that many urban women in Africa support their unemployed male partners, the wage employment motive should not be 
dismissed easily. Moreover, while the report's recognition of women's desire to escape their traditional village roles suggests an understanding of women's antipathy towards family-based production. Later, it makes the contradictory assertion that: 'some women avoid marriage in favour of arrangements which they see as giving them more personal and economic independence' (ILO/Abidjan: 77).

The report on Ethiopia highlights escape from drudgery as a motive for migration, while that on Jakarta stresses the search for employment. From the crowded land-scarce rural areas come the unemployed of both sexes. A 1954 migration survey showed that among all migrants the unemployment rate fell from 11.2 per cent before migration to 5.9 per cent afterwards. For women the change was more dramatic: from 32.2 per cent to 14.4 per cent (ILO/Jakarta: 114).

It is, of course, impossible to measure the relative importance in female migration of purely economic factors as against the desire to escape sexist oppression. However, there is enough evidence to suggest that escaping from rural patriarchy (both in the village and the family) is at least as strong a motive for women as for men, and that fleeing unremunerated, hard physical labour is not the same as merely responding to wage differentials. An understanding of this difference is crucial, yet many recent international policy recommendations formulated to counter migration to the cities are based on overcoming the disadvantages of rural society as seen through the eyes of men.

\section{Policy recommendations and their implications for women}

The ILO employment missions' major recommendation for overcoming rural unemployment was more intensive production methods on small farms for both crops and livestock raising. Both output per worker and output per unit of land should be raised through the application of better seeds and chemical inputs, but not necessarily through mechanisation. The consequent greater demand for labour would increase the total number of persons employed and their productivity.

This solution has been questioned on the grounds that it does considerably more to diminish both visible and invisible underemployment than open unemployment. The Colombia report, for instance, cautions that the main effect may be a reduction in the underemployed (mainly seasonal unemployment), while even in regions where a small scale peasantry predominates, nonmechanised intensification might lead to only slightly more job creation. The dilemma of distributing the work effort between increases in productivity of the labour that is employed and job creation is unresolved, while the important issue of whether it is landless men or landless women who obtain the new jobs is left unresolved. As far as job creation is concerned landless women, or women on uneconomic small plots, are unlikely to benefit as much as their male counterparts, and may well be worse off in absolute terms.

But even where the higher labour productivity of the employed is taken into account, we have to ask what is really meant by this before the implications for women can be judged. As one writer put it:

"There is some ambivalence in the way in which the concept of labour productivity is used in the (Colombia) report. Presumably the existence of a large stock of underutilized labour resources, mainly of a seasonal nature, may lead to an increase in the number of man-hours (mandays) of work per annum for farmers on the average, while output per man-hour rises only very slightly; but the implication is that the bulk of the growth in agricultural output is the result of high labour intensity rather than of growth of productivity per man-hour" (Thorbecke, 1973: 54).

The application of new labour techniques invariably means that more hours are worked, rather than a discernible increase in output per hour (examples are the new practice of straight row planting and more careful weeding). The result may be merely that visible underemployment will decline (or, in the case of women, overwork will increase), while invisible underemployment (low productivity work methods) remains the same. Neglect of this distinction due to the obsession with present visible underemployment of men permeates all the ILO reports. It was left to the report on Egypt to state that 'there is a negligible degree of underemployment of women amounting to 3 per cent for the whole year' (ILO/UAR: 61); and for the Kenya report to observe that amongst women there is no underutilized labour-rather the contrary (ILO/Kenya: 4 and 72).

In cases where mechanization is recommended to expand acreage under cultivation or allow for an additional crop each year, women in peasant households are bound to have to work under 
greater pressure, unless there is a change in the sexual division of labour which is unlikely since ideological constraints are slow to respond to changes in production methods. It is ironic that the task usually mechanized first, land preparation, is the traditional work of visibly underemployed men. Mechanization, then, would reduce typical male employment and increase peasant women's work burden.

Another cause for concern is seasonal variations. Although present seasonal variations in work loads are sharper for men than for women, when they do occur for women they come on top of five to six hours of domestic work. Some evidence suggests that the modern crop technologies can raise the level of the seasonal peaks of women's total daily work load well above men's to an almost intolerable level. Planting time is one such period, sharing in the harvesting of a larger crop another, and processing the harvest quickly before it rots the worst period of all. Situations differ, and in some, modern methods can moderate the seasonal peaks for women, but the outcome is serious enough for the welfare of women and children to deserve investigation before new practices are introduced. Even in Egypt, where women are assumed not to be economically active, it has been noted that the introduction of cotton (a typical ILO crop recommendation) intensifies the seasonal work period for women (ILO/UAR: $50)$.

Much of the rationale of the recommendations rests on the goal of raising family income. But no mention is made of the possible effects of these policies on the status of women within the peasant household. While it is recognised that many women are left alone to run the family farm, it is not suggested that they be regarded as the farmer, but rather implied that an agricultural intensification programme might encourage men to return. The Kenya report does take up some of the implications, particularly who should benefit from extension services and have access to the cash income earned through the transition from food crop to cash crop production-but the subject is quickly dropped before any suggestion that the person who cultivates-whether male or female-should be the member of the cooperative.

Land reform is mentioned frequently as an element of the agricultural intensification strategy (albeit as a medium to long term solution) but nowhere is the question of giving land to women raised. The Sri Lanka report discusses parents only giving land to their eldest son because of the scarcity of land: it suggests that in order to encourage farmers' sons to stay on the holding and work it, reforms should create a holding large enough to support a family-and, as yields rise, two or three families after a generation or so (ILO/Ceylon: 93).

What the policy involves is the capitalization of small-scale farming, using fuller-employed family labour, rather than the creation of new agricultural jobs. The conceptual model is a small capitalistic enterprise with a male entrepreneur at its head operating with the help of an official complex of input supply and extension information. There is no escaping the conclusion that the present proletarian (or, more accurately, serf) status of female household members would be further institutionalised, making outside intervention to improve women's personal status even more difficult. The only hope remaining to rural women is in the opportunities presented through multipurpose co-operatives and rural diversification. Otherwise, in their position as unpaid family labour, they must depend on the effect of higher income on living standards, a doubtful strategy unless the increase is very considerable.

The reports do comment on the possibilities for diversifying rural employment as a result of a successful agricultural intensification programme. They see new jobs opening in fertilizer factories, crop processing, manufacture of agricultural implements and machinery repair shops. However, most of these are likely to become male-typed, and nowhere is any apprehension expressed over women's roles as unpaid family labour being confirmed and strengthened, nor a sense of urgency about bringing directly remunerated work to women. At a time when so many planners are realising the importance of raising women's status through directly gainful employment and greater social visibility, the main plank of the economists' new thinking on employment and unemployment is to give women more 'man-days' of invisible, unpaid work in the family enterprise.

What of solutions to urban women's dilemma? The Kenya mission report listed its recommendations under services, the informal sector, and the formal sector. Since so much of the service industry has been regarded as part of the informal sector in the ILO mission reports, the recommendations are presented here together. They include:

-reviewing trade and commercial licensing with a view to liberalization and reducing the illegality of activities and improving free competition; 
-issuing licences to any applicant able to pay the licence fee;

-intensifying research and development work on products suitable for production or use in the informal sector, priority being given to capital and intermediate products, repairs and construction;

-inducing larger firms to train subcontractors and using industrial estates to promote subcontracting;

-encouraging government tendering of products and services from enterprises in the informal sector;

-promoting small scale enterprises in goods and services, especially on the basis of self-employment;

-increasing the emphasis of vocational training for service occupations;

-discouraging unnecessary mechanization of trade and personal services.

(ILO/Kenya: 20 and 22)

The main characteristics of these recommendations are easing entry, enhancing competition, promoting the self-employed, increasing vocational training and subcontracting, and protecting trade and personal services from mechanization.

THE ILO mission members were quite sure that women's employment would be assisted by the development of the informal sector, yet elsewhere they confess that many women are involved in informal sector activities (such as illegal beerbrawing and prostitution) which are difficult to cover even statistically. Moreover, women are often employed part-time in several different activities which must present formidable problems for upgrading their work. Another area of the informal sector where women predominate is sales and services. But it is difficult to see how labour productivity can be increased either here or in the domestic service industry.

With great heterogeneity amongst products and services as well as amongst methods of production in the informal sector, these recommendations, even if accepted, would have a very uneven impact over the sector as a whole. Vocational training, is probably over-rated, for once a woman knows how to work in small-scale manufacturing, such as using a sewing machine, there is little scope for further upgrading her productivity; rather the terms of her contract or sub-contract need amendent. It is virtually impossible to do anything for women in the informal services sector: with easy licensing and limited credit facilities, discrimination in favour of male applicants could put some women out of business. In this regard, the general criticism that upgrading informal sector enterprises in practice means upgrading the more viable ones with the result that the remaining one's become more economically insecure, is likely to be especially pertinent to women.

Some of the direct and indirect effects will depend on the constraints imposed on the style of formal sector (principally large factory) development. There is no need to quote the evidence on the capital intensity and poor employment record of this sector. The policy of importsubstitution followed by most developing countries has been widely condemned and most thinking in official circles is concerned with promotion of traditional exports. The Kenya report itself calls for a revision of the protection system and more export incentives.

The promotion of primary exports is likely to intensify the subordination of women in familybased agriculture. Moreover, the expansion of post-1945 manufacturing may have been dominated by import-substitution in Latin America and to a less extent in Asia, but it has also meant substitution of women's own cottage industry through the development of capital intensive industry. A change in scale and production method is more important to women than whether the product should be nationally produced or imported.

Thus the recommendation of some of the ILO mission reports to lower protective tariff rates on manufactured items can be questioned. The pattern of tariffs appropriate to promote employment and indigenous secondary industry will vary from country to country. Adjustments to the exchange rate which favour small industry and the use of local materials instead of imported inputs would be of assistance to local employment, especially women's.

Because policies directed at upgrading labour in the informal sector are unlikely to reach women's activities in that sector, and because women are discriminated against most when there is severe unemployment, any policy directed at increasing the number of jobs, even of poorly-paid jobs, is more important to women than to men. Thus the 
ILO recommendations to change the product-mix (composition of manufactured goods) in order to stimulate production of the more essential light consumer goods using more labour intensive methods are extremely important for urban women. A more even spread of skill requirements in the urban economy should also encourage new attitudes on the part of employees to the recruitment of women.

A final short term recommendation of some of the ILO mission reports is the establishment of employment exchanges. This would not only provide more information about jobs available but could be a first step towards monitoring the conditions of work in activities which so far have been outside legislation. Employment exchanges for domestic servants, for instance, could provide comparative information on wages and work conditions, and could be the basis for unionising women even in a situation of general unemployment.

The reports also recommended changes in education. Literacy skills should be mixed with more relevant general education and vocational training to 'redirect the aspirations of students and their parents'. This is somewhat vague! If it means more relevant skill training then it has to be said that although the real needs of the country may be for technicians and people of intermediate skills, with unemployment existing at all skill levels, re-orienting the education system towards them would appear to be premature. The Ethiopia report urges caution over planning trained manmanpower:

"It is simply not true that a growing economy 'requires' particular types of manpower, in the sense that it would fail to grow without them: it is almost always possible to ge tround the absolute lack of particular skills. No doubt, it takes a pilot to fly a plane and a surgeon to perform operations but it is misleading to carry such analysis right through the entire spectrum of occupations" (ILO/Ethoipia: 11).

For women this is particularly relevant. The very low levels of even primary education for girls in many countries points to a first priority in any redirection of educational resources. Some of the reports also recommended reviewing the curriculum of education extension for women, shifting the emphasis away from home economics towards managing new economic ventures and promoting women in the planning of extension work. Expanding functional literacy could well have been added.
Finally, population control is given a passing reference in all the reports as a long term solution to the imbalance between the rate of growth of the labour force and the availability of jobs given advancing technology. It is also seen as a means of reducing the dependency burden on households. But there may well be contradictions between the proposed policies and population limitation. The best strategy for population control remains the advancement of women so that they can make truly free choices, but the latest thinking on employment and unempolyment problems does not address itself to this issue.

\section{The Basic Needs Approach and women}

The Basic Needs Approach (BNA) was born out of disillusionment with the theory which maintained that prosperity amongst the skilled or capital-owning groups would slowly trickle down to the less entrepreneurial or disadvantaged. The first principle of BNA is that if benefits are ever to reach the poorest then development strategies must be rooted in their needs. It is highly relevant to women's issues, for taken to its logical conclusion it must confirm the argument that the wearier, more malnourished, more dependent sex, deserves special attention.

The second principle of the BNA is that production increases should initially be of essentials needed by the poorest, and produced by the poor themselves so that there is little chance of alienating consumption from production. Insofar as these industries will be more labour-intensive and increase the immediate availability of essentials relative to non-essentials, women's interests should be promoted.

The third principle of the BNA is that of participation of people in the decision-making process. As the background paper to the International Labour Office's 1976 World Employment Conference (ILO 1976: 32) puts it:

'For example, education and good health will facilitate participation, and participation in turn will strengthen the claim for the material basic needs'.

But feminists will face a couple of problems (at least) with this statement. One is that it assumes some initial improvement in either education and health or in participation in decision-making, yet how this is to come about for women is not specified. In the whole of the ILO document nothing is said of women's organisations, yet it is difficult to see how women can be reached or can 
join in new opportunities without being mobilised. The other problem is that nothing is said of women sharing access with men to decisionmaking, which will affect both their own and their husbands' economic opportunities. We can be sure that in the case of the first problem, it was assumed that a husband's participation would be the equivalent of his wife's. In the case of the second, this, of course, would be a family matter over which planners might be supposed to have no proper jurisdiction (even though all their policies inevitably interfere in relations of exchange between men and women).

The ILO's basic document distinguishes two categories of basic needs: adequate food, shelter and clothing consumed by the individual families; and safe drinking water, sanitation, public transport, health and education provided by the community. On the issue of rural women, the document points out that women's contribution to the satisfaction of the basic needs of the household is as great as, if not greater than that of men, but that their tasks are time-consuming and physically arduous. There are thus two facets to a basic needs strategy for women in developing countries. One is to enable them to contribute more effectively, within the framework of their traditional responsibilities, to the satisfaction of their families basic needs. The other is to ease their work burden while furthering their economic independence and their more equitable integration into the wider community beyond the narrow circle of the family. This recognition of women's fully stretched working day is a welcome advance on past thinking. But how this work burden is to be eased-bearing in mind that it is mainly unmonetised and unmarketed work -is not even hinted at.

One of the general criticisms of the BNA is that it does not stress the need for redistribution of land and other forms of wealth. This criticism can be made in even stronger terms as it applies to women. There is not even a mention of a redistribution of resources between the sexes: there is no reference to equal inheritance rights, of the resource requirements of mother-headed families, or of women's direct access to capital loans. But until woman's direct access to resources is specified, there can be no real realignment of economic opportunities and of rights of appropriation over the returns to those opportunities between the sexes. This leads directly to a second criticism: women, especially rural women traditionally produce a wide range of goods and services. The ILO document distinguishes require- ments for the satisfaction of basic needs provided by the family from those provided by the community. But some of the latter, such as water, power, health and sanitation, are met entirely by women, and as such are viewed as exacting no economic or human cost. At what stage, then, or under what social impetus, are these demands on women's time and energy to be transferred to the community?

The BNA lays considerable stress on providing for the unemployed in order to ensure that they have adequate income to purchase in greater quantities. This is simply the Kenya mission's emphasis on adequate employment for the working poor taken further. A number of points here could prove to be traps for women.

First, the focus is on currently unemployed labour, and this is largely male labour in rural areas. Second, it is implied that higher productivity methods should be concentrated on new employment rather than current work processes. Third, this new higher productivity employment will be in the wage sector of the local economy. Taken together, this would result in strong economic differentiation between those who are presently fully occupied and those absorbed by new employment.

While the BNA recognises that men and women approach the labour market from opposite endsfrom underutilisation and overwork respectivelyits emphasis on providing adequate employment presents a difficulty. If women are already fully stretched, they are not likely to be available for the new higher productivity jobs. They will probably continue to dominate home-making activities and self-provisioning food production, yet as we have already noted, these are just the jobs which are unlikely to be upgraded. The new technology and the new jobs will go to men. If this happens, the inequality of exchange as regards the relative labour productivities of the sexes will become greater and the obstacles to women's equitable integration in development must become greater. There may thus be a case for giving priority to changing women's present inadequate employment into adequate employment, even at the cost of retaining some male unemployment.

\section{Women and the New International Economic Order}

As aid, foreign investment and international trade failed to fulfill their promises of advancing the economies of developing countries, a closer look was given to production and trading structures and international economic institutions. Not surpris- 
ingly it was found that the highly imperfect capital and commodity (including technology) markets were operating to weaken the purchasing power and productivity of developing countries relative to the industrialised countries. Structural changes, rather than the workings of the free market were increasingly seen as the solution to the growing dualism between poor and rich countries. These changes have been outlined in a set of statements known as the New International Economic Order (NIEO).

So far NIEO includes several strategic targets for developing countries: higher and stable prices of primary products; the transfer of markets as well as technology to developing countries; and selfreliance in food. The little that has been written on the implications of these for women has centred on generalised optimism that higher prices for primary products will pass in the form of higher income to women in the farming community. But whether this will be personal or household income is never specified. The truth is that the effects of a NIEO on people, as distinct from national exchequers, depends heavily on pricing, marketing and investment decisions internal to the national economies of developing countries.

Insofar as higher and more stable prices for primary primary commodities accrue to producers in rural areas, women should benefit. There is, however, the danger that in taking advantage of better export returns, productivity improvements in rural areas will concentrate on export crops, and since their production is usually under the control of men-using family labour-rural women will not share equitably. The custodial role of male heads of household could also be strengthened and the backstop kitchen gardening status of women confimed. If, on the other hand, there were imaginative institution-building, incorporating women's interests, or if increased income were used for rural diversification, women could share in new employment opportunities, particularly if production were under their own control or under the control of an accounting unit other than the household.

Those who support NIEO argue that the transfer of technology and markets for urban-based products will promote a balance between capital intensity and job creation such that an internal dynamic is established. This should progressively reduce the numbers of urban unemployed while maintaining a steady rise in labour productivity. But it could equally come about that the conflict between capital intensity and job creation can be diminished by an arbitrary reduction in the presumed labour force. The temptation to eliminate women from calculations of the numbers to be satisfied in the urban wage market will be great. After all, in high income countries women are as a reserve army of labour. This same role of adopting high levels of technology, rather than 'second-best' intermediate technology. However the consequences of such a policy for the emancipation of women and for family poverty are quite negative for it is very unlikely that male wages will rise sufficiently to counter the loss of women's earnings.

What is being argued here is that the choice of the industrial product-mix under a NIEO should be determined not only by considerations of technology and markets, but also by criteria of woman's greater employment and labour productivity. Without this, hopes for a more integrated role for women will have to await the time when women, as a class of low productivity workers facing unemployment on a southern periphery, demand another new economic order.

\section{References}

International Labour Office, 1969, Rural Employment Problems in the United Arab Republic, Geneva

1971, A Programme of Action for Ceylon, Geneva 1972, Employment, Incomes and Equality: $A$ Strategy for Increasing Productive Employment in Kenya, Geneva

1973, Employment in A frica: Some Critical Issues, Geneva

1973, Employment and Unemployment in Ethiopia, Geneva

1976, The Employment Problem of Latin A merica, Facts, Outlooks, and Policies, ILO with PREALC, Santiago

1976, Employment, Growth and Basic Needs: $A$ One-World Problem, Geneva

Joshi, Heather, Harold Lubell and Jean Mouly, 1976, Abidjan: Urban Development and Employment in the Ivory Coast, ILO, Geneva

Lubell, Harold, 1976, Calcutta: Its Urban Development and Employment Prospects, ILO, Geneva

Singer, Hans and Richard Jolly, 1973, 'Unemployment in an African Setting: Lessons of the Employment Strategy Mission to Kenya', in Employment in Africa, ILO, Geneva

Schaefer, Kalmann, 1976, Saõ Paulo: Urban Development and Employment, ILO, Geneva

Sethuraman, S. V., 1976, Jakarta: Urban Development and Employment, ILO, Geneva

Thorbecke, Eric, 1973, 'The Employment Problem: A Critical Evaluation of Four ILO Comprehensive Country Reports', in Strategies for Employment Promotion, ILO, Geneva 